\title{
Anti-borreliae efficacy of selected organic oils and fatty acids
}

\author{
Anna Goc ${ }^{*} \mathbb{D}$, Aleksandra Niedzwiecki ${ }^{*}$ and Matthias Rath
}

\begin{abstract}
Background: Borrelia sp. is a causative pathogen of Lyme disease which has become a worldwide health concern. Non-toxic approaches especially directed toward latent persistent forms of this pathogen are desired. Lipids in the form of volatile and non-volatile oils, and fatty acids with proven anti-borreliae efficacy could become an additional support or an alternative for consideration in treatment approaches.

Methods: In this study we investigated 47 lipids (30 volatile and non-volatile oils, and 17 fatty acids) of plant and animal origin against typical motile, knob/round-shaped persisters, and biofilm-like aggregates of Borrelia burgdorferi s.S. and Borrelia garinii, which are identified as pathogenic factors of Lyme disease in the USA and Europe, using direct microscopic counting and spectrofluorometric measurements.

Results: Out of all examined lipids, 5 oils (Bay leaf oil, Birch oil, Cassia oil, Chamomile oil German, and Thyme oil) at or below 0.25\%, and 3 fatty acids (13Z,16Z Docosadienoic acid, erucic acid, and petroselinic acid) at or below 0.75 $\mathrm{mg} / \mathrm{ml}$, showed bactericidal activity against typical motile spirochetes and knob/round-shaped persisters. Only Bay leaf oil and Cassia oil, including their major constituents, eugenol and cinnamaldehyde, showed to target biofilmlike aggregates of both tested Borrelia spp. at the same concentration, although with 20-30\% eradication mark.

Conclusion: Based on obtained results, volatile oils were more potent than non-volatile oils, and unsaturated fatty acids were more effective than saturated fatty acids. Among all tested oils, Bay leaf oil and Cassia oil, with their major components eugenol and cinnamaldehyde, seem to have the highest anti-borreliae efficacy.
\end{abstract}

Keywords: Borrelia spp., Oils, Fatty acids, Spirochetes, Persisters, Biofilm-like aggregates

\section{Background}

Lyme disease (LD) is a multi-systemic zoonosis transmitted by ticks. According to the $\mathrm{CDC}$, it has become the most common vector-borne disease in Europe and Northern America. In the USA alone the number of diagnosed LD cases reaches 300,000 annually [1]. The causative factor of this illness is a bacterium of genus Borrelia which is an invasive, host-dependent, semiaerophilic, and slow-growing pathogen [2]. These features attribute to the long delays when diagnosing LD and, in many cases, a correct and precise diagnosis is a challenge. Currently, four predominant species are identified to cause LD: Borrelia burgdorferi s.s. and Borrelia mayonii (in North America) and Borrelia afzelii and Borrelia garinii (in Eurasia). All of the species can exist

\footnotetext{
* Correspondence: a.goc@drrath.com; a.niedz@drrath.com Department of Infectious Diseases, Dr. Rath Research Institute, 1260 Memorex Dr., Santa Clara, CA 95050, USA
}

in three morphological forms. The vegetative (active) form is the typical corkscrew motile spirochetes. Under stress conditions, including antibiotic exposure in vitro, they have the ability to quickly transform into latent persistent forms such as knob/round-shaped bodies (forms) and/or biofilm-like aggregates [3-6]. Although not fully proven and accepted, it is believed that these latent forms might be one of the possible causes of the infection persisting in animal and human organisms [7-11].

The primary and conventional treatment for Lyme patients is based on antibiotics, and the "first choice" of $\beta$-lactams and tetracyclines are administered for up to 3-4 weeks. Randomized clinical trials showed that for the acute (early) stage of LD this approach can be nearly $90 \%$ effective, as opposed to the late and persistent stages of this disease, whose etiology, although is still not clearly explained, points to lingering persisting infection as one of the reasons $[2,12-14]$. In addition,

(c) The Author(s). 2019 Open Access This article is distributed under the terms of the Creative Commons Attribution 4.0 International License (http://creativecommons.org/licenses/by/4.0/), which permits unrestricted use, distribution, and reproduction in any medium, provided you give appropriate credit to the original author(s) and the source, provide a link to the Creative Commons license, and indicate if changes were made. The Creative Commons Public Domain Dedication waiver (http://creativecommons.org/publicdomain/zero/1.0/) applies to the data made available in this article, unless otherwise stated. 
prolonged treatments with FDA-approved antibiotics are not recommended for pregnant women and patients with persistent LD (PTLDS, Post-Treatment Lyme Disease Syndrome), since their effectiveness has not been demonstrated, they are not cost-effective, and they are difficult to administrate, or may involve toxic side effects [1, 15-21]. Among patients suffering from chronic symptoms, approximately $20 \%$ of them remain without effective treatment [1]. The alternative non-antibiotic treatments are available but their efficacy has not yet been validated in clinical trials. One of the reasons might be the rather small number of compounds that have been studied thus far against Borrelia sp. [22-27]. However, naturally-derived substances, either in the form of the isolated active compounds, their metabolites, or plant-based extracts, have been a valuable source of non-synthetic and non-modified agents for human and animal health longer than the synthetic therapeutics [28-32]. Their potential as antimicrobials has been tested against an abundance of bacteria species. Lipid compounds have not yet been extensively studied as anti-borreliae agents. Their classification is rather unified and integrates a vast group of chemical compounds diverted in structure, properties, and function [33]. Lipids are commonly ascribed as hydrophobic viscous in ambient temperature compounds of plant, animal, or petrochemical origin. They encompass a class of molecules recognized as triglycerides, which are liquid in nature and called oils, as well fatty acids that are carboxylic acids with a long aliphatic chain, either saturated or unsaturated. Organic oils may be comprised in volatile or non-volatile groups with extensive use in industry, cosmetology, and food and medicine. Their remarkable applicability also evokes an interest as naturally occurring agents with broad antimicrobial characteristics [30-32].

Saturated or unsaturated fatty acids are the essential building blocks of other structurally complex lipids, and are important dietary sources of energy for animals. Thus, it is rational to study the biocidal potential of organic oils and fatty acids and validate their specific or general antimicrobial activity.

In this study, we tested 30 volatile and non-volatile organic oils, and 17 fatty acids against all known pleomorphic forms of Borrelia burgdorferi s.s. and Borrelia garinii. We evaluated their anti-borreliae effect using a "golden standard" method of direct counting and dark field microscopy, and the high throughput spectrofluorometric screening method to assess viability of the logarithmic phase (rich in typical motile spirochetes) and the stationary phase (rich in knob/round-shaped persisters) [20]. We also conducted quantitative testing of these lipids against biofilm-like aggregates of both studied Borrelia strains.

\section{Methods}

\section{Test compounds}

The test compounds and antibiotics with the purity between 90 and $98 \%$ according to the manufacturer, with the exception of the Greek sage oil (Salvia triloba) obtained from SunRose Aromatics, LLC (Morrill ME), the Bay leaf oil (Pimenta racemosa) obtained from Penn Herb Company, Ltd. (Philadelphia, PA), and 13Z,16Z docosadienoic acid purchased from Cayman Inc. (Ann Arbor, MI). Their selection was based on the literature review and potential applicability for commercial use as anti-borreliae agents. The stock solution $(25-50 \mathrm{mg} / \mathrm{ml})$ of each solid compound was prepared by suspending an individual test compound in DMSO and sterilizing with $0.22 \mu \mathrm{m}$ syringe filtration. All liquid (stock) compounds were also sterilized with $0.22 \mu \mathrm{m}$ syringe filtration. No difficulties were observed with dissolving the test lipids in DMSO.

\section{Test microorganisms}

Two Borrelia species, Borrelia burgdorferi sensu stricto and Borrelia garinii, were tested in their three morphological forms: typical motile spirochetes, persisters/knob (round)-shaped forms, and biofilm-like aggregates. Low passage isolates of the B31 strain of Borrelia burgdorferi and the CIP103362 strain of Borrelia garinii were obtained from the American Type Culture Collection (Manassas, VA). The B31 strain is an isolate from Ixodes dammini, and the CIP103362 strain is an isolate from Ixodes ricinus. Both Borrelia sp. were prepared for testing as previously reported [6, 24]. Briefly, the cryo-stocks of both species were cultured in commonly used conditions, i.e., Barbour-Stoner-Kelly H (BSK-H) medium supplemented with $6 \%$ rabbit serum (Sigma, St. Louis, $\mathrm{MO}$ ) without antibiotics at $33{ }^{\circ} \mathrm{C}$ with $5 \% \mathrm{CO}_{2}$, in $15 \mathrm{ml}$ polypropylene sterile test tubes, respectively. The homogeneous logarithmic culture (having only typical motile spirochetes/active form) of tested Borrelia sp. was obtained by maintaining inoculum in a shaking incubator at $33^{\circ} \mathrm{C}$ and $250 \mathrm{rpm}$ for $2-3$ days. Stationary culture (enriched in knob/round-shaped cells/persistent forms) of tested Borrelia sp. was generated by maintaining inoculum in an incubator at $33^{\circ} \mathrm{C}$ for $7-8$ days. Biofilm-like aggregates of tested Borrelia sp. were prepared by incubation of inoculums in four-well chambers (BD Biosciences, Sparks, MD) coated with collagen Type I from rat tail for at least 1 week.

\section{Evaluation of the anti-borreliae effects of test lipids against typical motile spirochetes and knob/round- shaped persisters of Borrelia spp.}

Testing was assessed using direct counting and spectrofluorimetry as previously described [26, 34]. Briefly, $1.8 \mathrm{ml}$ sterile screw-cap test tubes or 96-well plates with $1 \mathrm{ml}$ BSK-H medium, were inoculated 
with $2 \times 10^{6}-1 \times 10^{7}$ cells $/ \mathrm{ml}$ (logarithmic phase, i.e., 2-3 days culture or stationery phase, i.e., 7-8 days culture) and supplemented with the test compound in concentration ranging from 0.025 to $1.0 \%$ for liquid agents, and from $0.025 \mathrm{mg} / \mathrm{ml}$ to $1.0 \mathrm{mg} / \mathrm{ml}$ for solid agents. Controls were treated with DMSO $(0.1-0.4 \%)$ or triple combination of antibiotics (daptomycin+cefoperazone+doxycycline $)(0.03 \mathrm{mg} / \mathrm{ml}, 0.01 \mathrm{mg} / \mathrm{ml}$ each $)$ since this combination of antibiotics showed to be effective against the logarithmic phase and the stationary phase of Borrelia burgdorferi s.s. [20]. Next, the tubes and plates were incubated at $33{ }^{\circ} \mathrm{C}$ with $5 \% \mathrm{CO}_{2}$ up to $72 \mathrm{~h}$. Assessment was done using high throughput spectrofluorometric screening and/or direct counting with a bacterial Petroff-Hausser counting chamber and dark field microscopy, supported by SYBR Green I/PI staining and a fluorescence microscope (Nikon, Eclipse E600), respectively. The excitation wavelength was set at $485 \mathrm{~nm}$, and the fluorescence intensity at $535 \mathrm{~nm}$ (green emission) and $635 \mathrm{~nm}$ (red emission). Long-term sub-culture study was performed by transferring $50 \mu \mathrm{l}$ of the stationary phase of Borrelia sp. culture, previously treated with test lipid and washed with fresh BSK-H medium, to $1 \mathrm{ml}$ of fresh agent-free $\mathrm{BSK}-\mathrm{H}$ medium for 14 days. The tubes were then incubated at $33{ }^{\circ} \mathrm{C}$ with $5 \% \mathrm{CO}_{2}$ and bacterial proliferation was assessed using a bacterial Petroff-Hausser counting chamber with a dark field microscope and SYBR Green I/PI staining with a fluorescence microscope (Nikon, Eclipse E600) [34]. All experiments were conducted three times independently and each one in three replicates.

\section{Evaluation of anti-borreliae effects of the test lipids against biofilm-like aggregates of Borrelia spp.}

Quantitative anti-borreliae effect of the test compounds against biofilm-like aggregates was assessed in four-well chambers coated with collagen Type I from rat tail (Sigma, St. Louis, MO) as described $[5,6,26]$. Briefly, $1 \times 10^{7}$ cells $/ \mathrm{ml}$ was inoculated into each sterile chamber filled with $1 \mathrm{ml}$ BSK-H medium, and incubated for 1 week at $33{ }^{\circ} \mathrm{C}$ with $5 \% \mathrm{CO}_{2}$, followed by $72 \mathrm{~h}$ of incubation with the test lipids. Control wells received DMSO $(0.1-0.4 \%)$ or the triple combination of antibiotics (daptomycin+cefoperazone+doxycycline $) \quad(0.03 \mathrm{mg} / \mathrm{ml}, \quad 0.01$ $\mathrm{mg} / \mathrm{ml}$ each). Eradication of biofilm-like structures was assessed by using the crystal violet $(\mathrm{CV})$ staining method as previously reported [5]. Briefly, all wells were fixed with $500 \mu \mathrm{l}$ of cold methanol-formalin (1:1) for $30 \mathrm{~min}$. and stained with $1 \mathrm{ml}$ of $\mathrm{CV}(0.1 \%)$ for $10 \mathrm{~min}$. Next, the biofilms were carefully washed three times with $1 \times$ PBS (phosphate-buffered saline), and $1 \mathrm{ml}$ of methanol was added to each well to extract a dye which was measured at $595 \mathrm{~nm}$ using a spectrophotometer (Molecular Device, Spectra Max 340). In addition, all wells were fixed with
$500 \mu \mathrm{l}$ of cold formalin acetic acid mixture for $20 \mathrm{~min}$., followed by staining with $200 \mu \mathrm{l}$ of BacLight staining kit (Thermo Fisher, Waltham, MA) for $15 \mathrm{~min}$. in the dark, according to the manufacturer's recommendation. Pictures were immediately taken from untreated and treated mounted slides using a fluorescence microscope (Nikon, Eclipse E600). Earlier studies in our laboratory have documented a lack of antifungal carryover using this procedure [24]. All experiments were conducted three times independently and each one in three replicates.

\section{Statistical analysis}

All data are presented as means $\pm \operatorname{SD}(n=3)$. The Student's two-tailed t test was used to determine statistically significant differences set at 0.05 levels. Statistical analysis was performed using GraphPad software.

\section{Results}

The bactericidal efficacy of selected lipid compounds against typical motile spirochetes (logarithmic phase) and knob/round-shaped persisters (stationary phase) of Borrelia burgdorferi s.s. (B31 strain) and Borrelia garinii (CIP103362 strain) are presented as the minimal bactericidal (MBC) concentrations in Tables 1 and 2. The results showed that among 30 tested oils, 22 expressed bactericidal activity against typical corkscrew motile spirochetes and knob/round-shaped persisters and the MBC values fluctuated between 0.15 and $1 \%$. Out of all 17 tested fatty acids, 8 revealed the killing effect at the concentrations between $0.5 \mathrm{mg} / \mathrm{ml}$ and $1.0 \mathrm{mg} / \mathrm{ml}$. The $\mathrm{MBC}$ values corresponded to each other for both tested Borrelia sp. The triple combination of antibiotics (daptomycin+cefoperazon+doxycycline) at the concentration of $0.03 \mathrm{mg} / \mathrm{ml}(0.01 \mathrm{mg} / \mathrm{ml}$, each) was used as a positive control since this combination at this particular concentration was previously reported to be effective against both typical motile spirochetes and knob/round-shaped persisters of Borrelia burgdorferi [20, 26].

The results obtained from spectrofluorometric measurements have been further validated by direct counting using a dark field microscope and a fluorescence microscope for Bay leaf oil, Cassia oil and 13Z,16Z docosadienoic acid, all selected as agents with the highest anti-borreliae efficacy among all compounds tested in this study (Table 3). The results corroborated the data obtained from spectrofluorometric assay and, in addition, revealed that minimal inhibitory (MIC) values for Bay leaf oil and Cassia oil was $0.005 \%$, and $0.025 \mathrm{mg} / \mathrm{ml}$ for 13Z,16Z docosadienoic acid. Moreover, bactericidal effect of these three lipids was time-dependent with the $\mathrm{MBC}_{50}$ value achieved after $24 \mathrm{~h}$ (Fig. 1). Also, in this set of experiments additional examination was performed to find out which of the active components in the most effective oils (Bay leaf oil, Birch oil, Cassia oil, Chamomile oil German, 
Table 1 Bactericidal efficacy of organic oils against logarithmic and stationary phases of Borrelia burgdorferii s.s. and Borrelia garinii

\begin{tabular}{|c|c|c|c|c|}
\hline \multirow[t]{2}{*}{ Tested oils } & \multicolumn{2}{|c|}{ Borrelia burgdorferi s.s. } & \multicolumn{2}{|l|}{ Borrelia garinii } \\
\hline & $\begin{array}{l}\text { Logarithmic phase } \\
\mathrm{MBC}_{90}(\%)\end{array}$ & $\begin{array}{l}\text { Stationary phase } \\
\mathrm{MBC}_{90}(\%)\end{array}$ & $\begin{array}{l}\text { Logarithmic phase } \\
\mathrm{MBC}_{90}(\%)\end{array}$ & $\begin{array}{l}\text { Stationary phase } \\
\mathrm{MBC}_{90}(\%)\end{array}$ \\
\hline Arnica oil & $N S^{a}$ & $N S^{a}$ & $N S^{a}$ & $N S^{a}$ \\
\hline Avocado oil & $N S^{a}$ & $N S^{a}$ & $N S^{a}$ & $N S^{a}$ \\
\hline Bay leave oil (Pimenta racemosa) & 0.15 & 0.15 & 0.15 & 0.15 \\
\hline Birch (sweet) oil & 0.25 & 0.25 & 0.25 & 0.25 \\
\hline Black pepper oil & 1.0 & 1.0 & 1.0 & 1.0 \\
\hline Black seed oil & 1.0 & 1.0 & 1.0 & 1.0 \\
\hline Borage oil & 1.0 & 1.0 & 1.0 & 1.0 \\
\hline Cassia oil & 0.15 & 0.15 & 0.15 & 0.15 \\
\hline Coconut oil & $N S^{a}$ & $N S^{a}$ & $N S^{a}$ & $N S^{a}$ \\
\hline Coriander oil & 1.0 & 1.0 & 1.0 & 1.0 \\
\hline Chamomile oil (German) & 0.25 & 0.25 & 0.25 & 0.25 \\
\hline Chamomile oil (Roman) & 1.0 & 1.0 & 1.0 & 1.0 \\
\hline Fennel oil & 1.0 & 1.0 & 1.0 & 1.0 \\
\hline Grape seed oil & $N S^{a}$ & $N S^{a}$ & $N S^{a}$ & $N S^{a}$ \\
\hline Greek Sage oil (Salvia triloba) & 0.75 & 0.75 & 0.75 & 0.75 \\
\hline Helichrysum oil & 1.0 & 1.0 & 1.0 & 1.0 \\
\hline Hyssop oil & 0.75 & 0.75 & 0.75 & 0.75 \\
\hline Jasmin oil & 0.75 & 0.75 & 0.75 & 0.75 \\
\hline Juniper oil & $N S^{a}$ & $N S^{a}$ & $N S^{a}$ & $N S^{a}$ \\
\hline Laurel leaf (Laurus nobilis) & 0.50 & 0.50 & 0.50 & 0.50 \\
\hline Myrrh oil & 0.75 & 0.75 & 0.75 & 0.75 \\
\hline Nutmeg oil & 0.75 & 0.75 & 0.75 & 0.75 \\
\hline Olive oil & $N S^{a}$ & $N S^{a}$ & $N S^{a}$ & $N S^{a}$ \\
\hline Pumpkin seed oil & 0.75 & 0.75 & 0.75 & 0.75 \\
\hline Pine needle oil & 0.75 & 0.75 & 0.75 & 0.75 \\
\hline Safflower oil & $N S^{a}$ & $N S^{a}$ & $N S^{a}$ & $N S^{a}$ \\
\hline Sunflower oil & $N S^{a}$ & $N S^{a}$ & $N S^{a}$ & $N S^{a}$ \\
\hline Tarragon oil & 1.0 & 1.0 & 1.0 & 1.0 \\
\hline Thyme & 0.2 & 0.2 & 0.20 & 0.20 \\
\hline Turmeric oil & 0.75 & 0.75 & 0.75 & 0.75 \\
\hline White camphor oil & 0.75 & 0.75 & 0.75 & 0.75 \\
\hline
\end{tabular}

Abbreviations: $\mathrm{MBC}_{90}$-minimal bactericidal concentration causing at least $90 \%$ of killing assessed by spectrofluorimetry after $72 \mathrm{~h}$ of treatment; ${ }^{\mathrm{a}}$-maximal tested concentration (i.e., 1\%), NS-not susceptible/not satisfying $\mathrm{MBC}_{90}$ requirement at the maximal tested concentration

and Thyme oil) could be responsible for observed anti-borreliae effect. The results revealed that $0.125 \%$ of eugenol (present in Bay leaf oil), 0.25\% of methyl salicylate (present in Birch [sweet] oil), 0.125\% cinnamaldehyde (present in Cassia oil), $0.10 \mathrm{mg} / \mathrm{ml}$ of chamazulene (present in Chamomile oil German), and $0.20 \mathrm{mg} / \mathrm{ml}$ thymol (present in Thyme oil), could be the constituents with bactericidal activity in contrast to other active ingredients present in these oils that did not show such activity [35-39]. There were no significant differences in efficacy of these compounds between both tested Borrelia spp.
The results of the 14-day sub-culturing study were performed as described previously $[26,27]$ to verify the killing effect of the stationary phase of Bay leaf oil and Cassia oil, including their major active component cinnamaldehyde and eugenol, as well as 13Z,16Z docosadienoic acid, are presented in Fig. 2. They show that Bay leaf oil at $0.15 \%$ concentration, or $0.125 \%$ eugenol as well as Cassia oil, or $0.125 \%$ cinnamaldehyde, were able to repopulate the fresh BSK-H media with predominantly live cells in $0.1-0.3 \%$. Treatment with the triple antibiotic combination $(0.03 \mathrm{mg} / \mathrm{ml})$ resulted in 
Table 2 Bactericidal efficacy of fatty acids against logarithmic and stationary phases of Borrelia burgdorferii s.s. and Borrelia garinii

\begin{tabular}{|c|c|c|c|c|}
\hline \multirow[t]{2}{*}{ Tested fatty acids } & \multicolumn{2}{|c|}{ Borrelia burgdorferi s.s. } & \multicolumn{2}{|l|}{ Borrelia garinii } \\
\hline & $\begin{array}{l}\text { Logarithmic phase } \\
\mathrm{MBC}_{90}(\mathrm{mg} / \mathrm{ml})\end{array}$ & $\begin{array}{l}\text { Stationary phase } \\
\mathrm{MBC}_{90}(\mathrm{mg} / \mathrm{ml})\end{array}$ & $\begin{array}{l}\text { Logarithmic phase } \\
\mathrm{MBC}_{90}(\mathrm{mg} / \mathrm{ml})\end{array}$ & $\begin{array}{l}\text { Stationary phase } \\
\mathrm{MBC}_{90}(\mathrm{mg} / \mathrm{ml})\end{array}$ \\
\hline \multicolumn{5}{|l|}{ Polyunsaturated } \\
\hline Linolenic acid & $N S^{\mathrm{a}}$ & $N S^{\mathrm{a}}$ & $N S^{a}$ & $N S^{a}$ \\
\hline Eicosapentaenoic acid & $N S^{a}$ & $N S^{a}$ & $N S^{a}$ & $N S^{a}$ \\
\hline Docosahexaenoic acid & $N S^{a}$ & $N S^{a}$ & $N S^{a}$ & $N S^{a}$ \\
\hline Linoleic acid & 1.0 & 1.0 & 1.0 & 1.0 \\
\hline 13Z,16Z Docosadienoic acid & 0.5 & 0.5 & 0.5 & 0.5 \\
\hline \multicolumn{5}{|l|}{ Monounsaturated } \\
\hline Undecenoic acid & $N S^{\mathrm{a}}$ & $N S^{a}$ & $N S^{a}$ & $N S^{a}$ \\
\hline Palmitoleic acid & $N S^{a}$ & $N S^{a}$ & $N S^{a}$ & $N S^{a}$ \\
\hline Oleic acid & 1.0 & 1.0 & 1.0 & 1.0 \\
\hline Erucic acid & 0.75 & 0.75 & 0.75 & 0.70 \\
\hline Petroselinic acid & 0.75 & 0.75 & 0.75 & 0.75 \\
\hline \multicolumn{5}{|l|}{ Saturated } \\
\hline Butyric acid & 1.0 & 1.0 & 1.0 & 1.0 \\
\hline Undecanoic acid & $N S^{a}$ & $N S^{a}$ & $N S^{a}$ & $N S^{a}$ \\
\hline Caprylic acid & $N S^{a}$ & $N S^{a}$ & $N S^{a}$ & $N S^{a}$ \\
\hline Myristic acid & $N S^{a}$ & $N S^{a}$ & $N S^{a}$ & $N S^{a}$ \\
\hline Palmitic acid & $N S^{a}$ & $N S^{a}$ & $N S^{a}$ & $N S^{a}$ \\
\hline Stearic acid & $N S^{a}$ & $N S^{a}$ & $N S^{a}$ & $N S^{a}$ \\
\hline Arachidic Acid & 1.0 & 1.0 & 1.0 & 1.0 \\
\hline Dox + Dap+Cef & 0.03 & 0.03 & 0.03 & 0.03 \\
\hline
\end{tabular}

Abbreviations: $\mathrm{MBC}_{90}$-minimal bactericidal concentration causing at least $90 \%$ of killing assessed using spectrofluorimetry after $72 \mathrm{~h}$ of treatment, Dox doxycycline, Dap daptomycin, Cef cefoperazon, ${ }^{\text {a }}$-maximal tested concentration (i.e., $1 \%$ ), NS-not susceptible/not satisfying $\mathrm{MBC}_{90}$ requirement at the maximal tested concentration

$\sim 10-12 \%$ of viable cells as previously reported [26], and a $24 \%$ increase in the number of viable cells treated

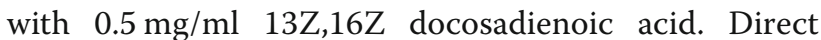
microscopic counting confirmed the results obtained with the SYBR Green I/PI assay.

Evaluation of biofilm-like structures grown on collagen-coated surface did not show the eradication of the biofilm-like aggregates when treated with 13Z,16Z docosadienoic acid. This was in contrast to Bay leaf oil and eugenol, as well as Cassia oil and cinnamaldehyde, although biofilm decrease was at a range of 20-30\% (Fig. 3). Treatment with the triple antibiotic combination did not have any significant effect on Borrelia biofilm-like structures grown on collagen surface, as published earlier [26].

\section{Discussion}

Naturally occurring compounds have been widely used in many aspects of human health for centuries [28-32, 40-43]. They have been extensively studied for their antimicrobial properties as well. Derived from a variety of biological sources such as plants, herbs, spices, and fruits, they have shown activity against a plethora of viruses, bacteria and fungi species, and are effective as food preservatives [44-47]. In addition, naturally-derived substances form the structural basis for developing new synthetic or semi-synthetic agents [29].

To date, most of the compounds investigated against Borrelia sp. belong to the polyphenols with only one study thus far that investigated volatile oils $[25,27]$. The authors of this study concluded that the most active essential oils were oregano oil, cinnamon oil, and clove oil, displaying higher efficacy than daptomycin, an antibiotic shown to kill Borrelia's persister. This study also indicated that oregano oil and its major constituent, carvacrol, are the most effective against the stationary phase of Borrelia burgdorferi with the ability of targeting biofilm-like clumps [27]. However, studies investigating other classes of lipid molecules such as fatty acids are lacking.

Our in vitro study expanded the pool of volatile oils to non-volatile oils and other classes of lipids such as fatty acids. The results indicate that out of 30 examined oils, Bay leaf oil and Cassia oil showed the highest anti-borreliae bacteriostatic and bactericidal effect, and 
Table 3 Bacteriostatic and bactericidal efficacy of selected lipids and its active components against logarithmic and stationary phases of Borrelia burgdorferii s.s. and Borrelia garinii

\begin{tabular}{|c|c|c|c|c|c|c|}
\hline \multirow[t]{3}{*}{ Tested agents } & \multicolumn{3}{|c|}{ Borrelia burgdorferi s.s. } & \multicolumn{3}{|c|}{ Borrelia garinii } \\
\hline & \multicolumn{2}{|c|}{ Logarithmic phase } & \multirow{2}{*}{$\begin{array}{l}\text { Stationary phase } \\
\mathrm{MBC}_{90}\end{array}$} & \multicolumn{2}{|c|}{ Logarithmic phase } & \multirow{2}{*}{$\begin{array}{l}\text { Stationary phase } \\
\mathrm{MBC}_{90}\end{array}$} \\
\hline & $\mathrm{MIC}$ & $\mathrm{MBC}_{90}$ & & MIC & $\mathrm{MBC}_{90}$ & \\
\hline Bay leaf oil & $0.0005 \%$ & $0.15 \%$ & $0.15 \%$ & $0.0005 \%$ & $0.15 \%$ & $0.15 \%$ \\
\hline Eugenol & $0.0003 \%$ & $0.125 \%$ & $0.125 \%$ & $0.0003 \%$ & $0.125 \%$ & $0.125 \%$ \\
\hline Birch oil & $0.00075 \%$ & $0.25 \%$ & $0.25 \%$ & $0.00075 \%$ & $0.25 \%$ & $0.25 \%$ \\
\hline Methyl Salicylate & $0.00075 \%$ & $0.25 \%$ & $0.25 \%$ & $0.00075 \%$ & $0.25 \%$ & $0.25 \%$ \\
\hline Cassia oil & $0.0005 \%$ & $0.15 \%$ & $0.15 \%$ & $0.0005 \%$ & $0.15 \%$ & $0.15 \%$ \\
\hline Cinnamaldehyde & $0.0003 \%$ & $0.125 \%$ & $0.125 \%$ & $0.0003 \%$ & $0.125 \%$ & $0.125 \%$ \\
\hline Chamomile oil & $0.0075 \%$ & $0.25 \%$ & $0.25 \%$ & $0.0075 \%$ & $0.25 \%$ & $0.25 \%$ \\
\hline Chamazulene & $0.01 \mathrm{mg} / \mathrm{ml}$ & $0.10 \mathrm{mg} / \mathrm{ml}$ & $0.10 \mathrm{mg} / \mathrm{ml}$ & $0.01 \mathrm{mg} / \mathrm{ml}$ & $0.10 \mathrm{mg} / \mathrm{ml}$ & $0.10 \mathrm{mg} / \mathrm{ml}$ \\
\hline a-bisabalol & $N S^{a}$ & $N S^{a}$ & $N S^{a}$ & $N S^{a}$ & $N S^{a}$ & $N S^{a}$ \\
\hline Thyme oil & $0.0005 \%$ & $0.20 \%$ & $0.20 \%$ & $0.0005 \%$ & $0.20 \%$ & $0.20 \%$ \\
\hline Thymol & $0.02 \mathrm{mg} / \mathrm{ml}$ & $0.20 \mathrm{mg} / \mathrm{ml}$ & $0.20 \mathrm{mg} / \mathrm{ml}$ & $0.025 \mathrm{mg} / \mathrm{ml}$ & $0.20 \mathrm{mg} / \mathrm{ml}$ & $0.20 \mathrm{mg} / \mathrm{ml}$ \\
\hline$\gamma$-terpinene & $N S^{a}$ & $N S^{a}$ & $N S^{a}$ & $N S^{a}$ & $N S^{a}$ & $N S^{a}$ \\
\hline 13Z,16Z Docosadienoic acid & $0.025 \mathrm{mg} / \mathrm{ml}$ & $0.50 \mathrm{mg} / \mathrm{ml}$ & $0.50 \mathrm{mg} / \mathrm{ml}$ & $0.025 \mathrm{mg} / \mathrm{ml}$ & $0.05 \mathrm{mg} / \mathrm{ml}$ & $0.50 \mathrm{mg} / \mathrm{ml}$ \\
\hline
\end{tabular}

Abbreviations: MIC-minimal bacteriostatic concentration causing at least $90 \%$ of growth inhibition assessed by direct courting using dark field microscopy after 72 $\mathrm{h}$ of treatment $\mathrm{MBC}_{90}-$ minimal bactericidal concentration causing at least $90 \%$ of killing assessed using by direct courting using fluorescence microscopy after 72 $\mathrm{h}$ of treatment, ${ }^{\mathrm{a}}$-maximal tested concentration (i.e., $1 \%$ ), NS-not susceptible/not satisfying $\mathrm{MIC} / \mathrm{MBC}_{90}$ requirement at the maximal tested concentration

moderate eradication effect of biofilm-like structures grown on collagen-coated surface. Additional evaluation of different concentrations of these two oils as well as their main active components, eugenol and cinnamaldehyde, displayed anti-borreliae effects in a time-dependent killing manner, which might point to a specific rather than non-specific mode of action. Interestingly, active ingredients in the most effective oils present in the highest amounts in these oils were responsible for observed anti-borreliae effect. One example is the difference between efficacy of Chamomile oil Roman and Chamomile oil German with the latter being more potent but also containing a higher amount of chamazulene [37]. In regards to fatty acids, out of the 17 tested, 13Z,16Z docosadienoic acid showed most bacteriostatic and bactericidal effect. In contrast to the oils, none of these compounds significantly affected biofilm-like structures of Borrelia spp. when used at a concentration sufficient to kill the logarithmic phase and the stationary phase of bacteria.

In order to find out whether viable cells can regrow after a 14-day period in the absence of test lipids, we conducted sub-culturing experiments using the lipid-treated stationary phase by transferring its $1 / 20$ portion into fresh culture medium. This study revealed that both Bay leaf oil and Cassia oil and their main ingredients (eugenol and cinnamaldehyde) are effective biocides, since no regrowth of viable cells was detected after a 14-day subculture. This was in contrast to $13 \mathrm{Z}, 16 \mathrm{Z}$ docosadienoic where $~ 24 \%$ regrowth was observed. The $0.03 \mathrm{mg} / \mathrm{ml}(0.003 \%)$ triple antibiotic combination (daptomycin, doxycycline, and cefoperazone) was effective against typical motile spirochetes and knob/round-shaped persisters, but not biofilm-like aggregates grown on collagen surface, and treatment with the triple antibiotic combination resulted in $\sim 11 \%$ regrowth of viable cells, as reported previously [26].

Antibacterial efficacy of Bay leaf oil (Pimenta racemosa) often misled with Laurel leaf (Laurus nobilis), Birch oil (Betula lenta), and Cassia oil (Cinnamomum cassia) misled with Cinnamon oil (Cinnamomum zeylanicum), in contrast to other volatile oils included in this study, e.g. Chamomile oil German (Matricaria chamomilla), Chamomile oil Roman (Chamaemelum nobile), Laurel leaf (Laurus nobilis), Thyme oil (Thymus vulgaris), etc., have not been extensively studied by other research groups against gram-positive and gram-negative bacteria, and there is no record about their anti-borreliae efficacy [48-52]. However, it is worth mentioning that Feng, et al, recently reported about the profound efficacy of Clove oil (Syzygium aromaticum), Cinnamon oil (Cinnamomum zeylanicum), and Oregano oil (Origanum vulgare) with its main component carvacrol, against the stationary phase of Borrelia burgdorferi at the $\mathrm{MBC}_{90}$ value established to be at or above $0.1 \%$.

Efficacy of active ingredients of the oils tested in this study and shown to be the most effective against Borrelia burgdorferi s.s. and Borrelia garinii such as eugenol, methyl salicylate, cinnamaldehyde, chamazulene, and thymol, against resistant and non-resistant gram-positive and gram-negative bacteria has been demonstrated more broadly $[30,31,39,48-54]$. Interestingly, it was 



\section{C}
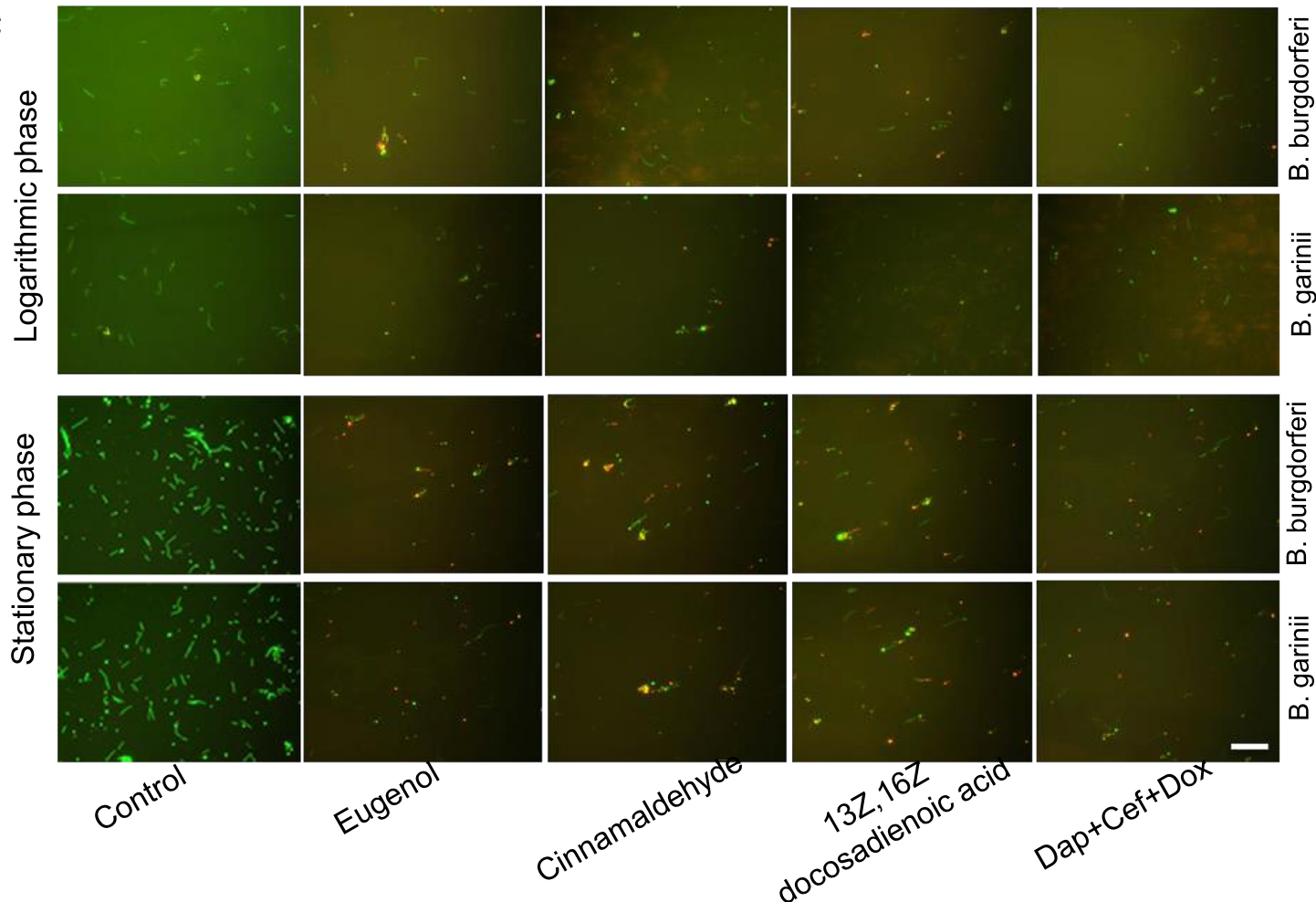

Fig. 1 Kinetic evaluation of anti-borreliae effects of selected lipids. Time-dependent killing efficacy of test lipids (oils at 0.15\% including their active ingredients at $0.125 \%$ concentration, 13Z,16Z-docosadienoic acid at concentration $0.5 \mathrm{mg} / \mathrm{ml}$ ) against logarithmic and stationary phases of Borrelia burgdorferi s.s. (a) and Borrelia garinii (b) monitored up to $72 \mathrm{~h}$ using direct counting and fluorescence microscope; ${ }^{*} p \leq 0.001$ compared to control. Representative live (green)/dead (red) merged images of logarithmic phase and stationary phase of Borrelia burgdorferii s.s. and Borrelia garinii (c) after $24 \mathrm{~h}$ incubation period with eugenol and cinnamaldehyde, as the active compounds of the most effective oils, 13Z,16Z-docosadienoic acid, and daptomycin+cefoperazone+doxycycline (Dap+Cef + Dox) as a positive control, taken at 200 x magnification, stained with BacLight dye; scale bar $50 \mu m$

chamazulene and not $\alpha$-bisabalol, which are both present in Chamomile oil German, to be responsible for anti-borreliae effect. Reported MBC values depend on the species and their resistance, and range from 0.01 to $1.9 \%$, with the noticeable pattern of higher bactericidal concentrations being effective against their latent forms, clinical isolates and resistant strains [52]. MBC values obtained in our study have corroborated the ranges of those already reported. As well, the same efficacy was found to be against the logarithmic phase (enriched in typical motile spirochetes) and the stationary phase (enriched in persisters). Eugenol and cinnamaldehyde, as representatives of phenylpropanoids, were found to be especially effective against typical motile, knob/roundshaped persisters, and the micro-colonies of studied Borrelia spp. as presented in Figs. 1, 2 and 3. Interestingly, these compounds are major parts of many essential oils and powdered extracts that showed to be active against a plethora of other microbials such as viruses, yeasts, molds, and gram-positive and gram-negative bacteria, including 


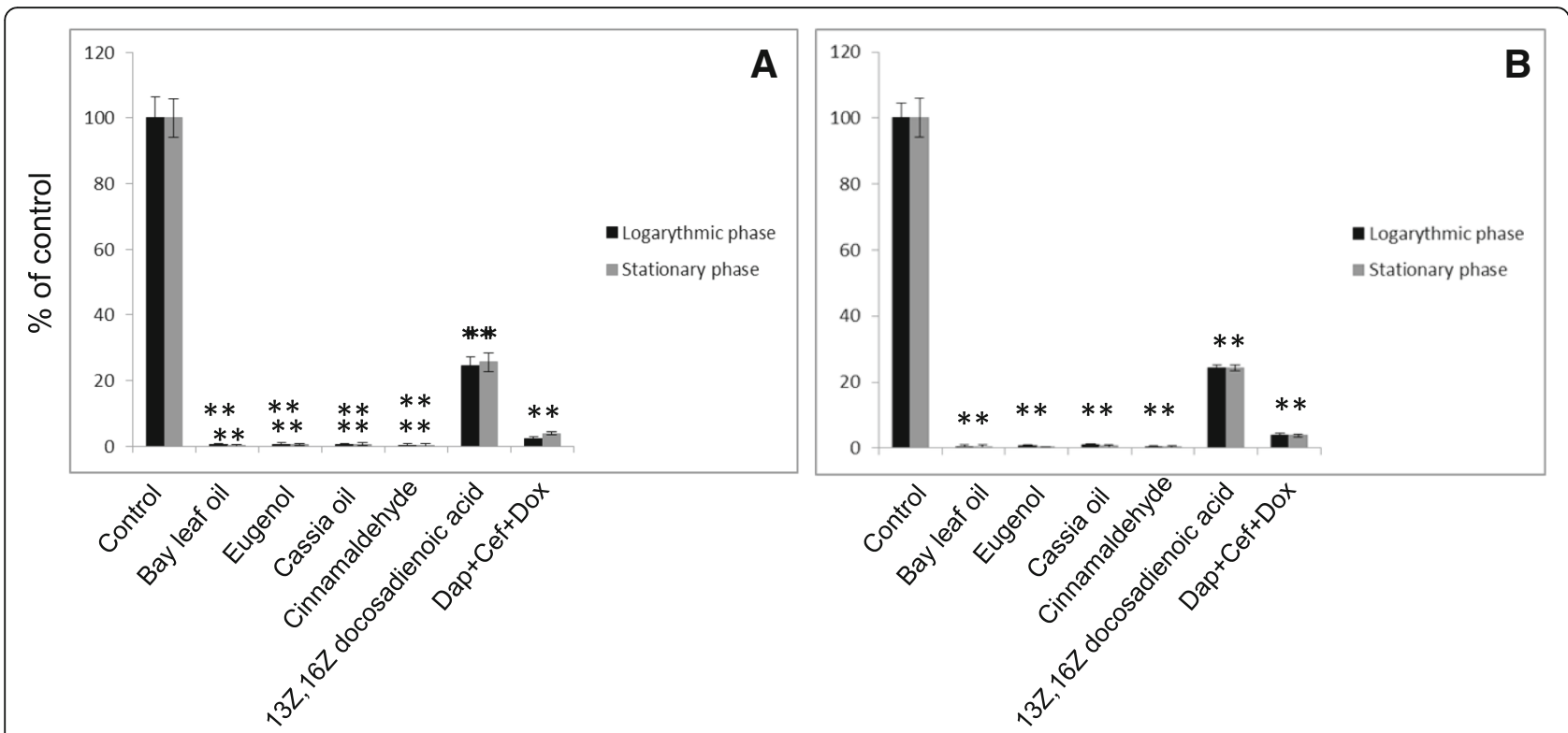

Fig. 2 Estimation of repopulated spirochete forms of Borrelia spp. Borrelia burgdorferi s.s. (a) and Borrelia garinii (b) were treated with test lipid (oils at $0.15 \%$ including their active ingredients at $0.125 \%$ concentration, $13 Z, 16 Z$ docosadienoic acid at concentration $0.5 \mathrm{mg} / \mathrm{ml}$ ) for $72 \mathrm{~h}$ and transferred to fresh tubes containing BSK-H medium only. After 14 days of sub-culturing, the presence of typical motile spirochetes were determined by SYBR Green I/PI assay using direct counting and fluorescence microscope; Dap+Cef + Dox - daptomycin+cefoperazone +doxycycline (as a positive control); ${ }^{*} p \leq 0.001$ compared to control

resistant strains and biofilms. It is also worth mentioning their anti-oxidant properties and their commercial applications in food flavorings, cosmetics, dentistry, and dermal drug delivery [55, 56]. Moreover, eugenol and cinnamaldehyde have recently become a focus of interest due to their anti-cancer and anti-inflammatory potential $[57,58]$. They have attracted a lot of interest for their bioactivities and applicability in agriculture as well $[50,55,56]$. Furthermore, these molecules are known to react with some enzymes and/or receptors consequently generating diverse therapeutically relevant pharmacological functions. Thus, these compounds are very promising candidates for versatile applications. Although the metabolism and pharmacokinetics of these compounds in humans have been studied, their therapeutic usage still remains to be further explored, and likewise research on chemical syntheses and modifications have been carried out to obtain compounds with more effective bioactivity. Finally, it is important to note that the effects of these two compounds on bacterial morphology has been observed, rendering possible action mostly towards their cell and mitochondrial membrane and the function of key survival-related metabolic enzymes [53, 54]. Thus, being hydrophobic in nature they are effective biocidal agents. However, cellular adaptation to these oils has not yet been reported, although it cannot be excluded.

There are numerous studies evaluating antibacterial properties of saturated and unsaturated fatty acids, but none relate to their anti-borreliae effects. Moreover, fatty acids operating as key components of antimicrobial food additives inhibiting the growth of undesirable microorganisms are well documented [40, 41, 59-61]. Besides the common fatty acids, it has been reported about their derivatives showing potent antimicrobial activities [41]. Interestingly, the antibacterial efficacy of fatty acids is usually ascribed to long-chain unsaturated fatty acids rather than generally less effective long-chain saturated fatty acids [41, 62]. It is also worth mentioning that long-chain unsaturated fatty acids are biocidal against well-known pathogens such as Methicillin-resistant Staphylococcus aureus, Helicobacter pylori, Mycobacteria sp., Bacillus sp. and Streptococcus sp. [62-66].

Based on our study we concluded that unsaturated fatty acids were more potent than saturated fatty acids against Borrelia spp. Moreover, the most effective were the fatty acids that have $18-22$ carbons such as polyunsaturated 13Z,16Z docosadienoic acid (omega 6, $\mathrm{C}_{22}$ ), as well as monounsaturated erucic acid (omega 9, $\mathrm{C}_{22}$ ) and petroselinic acid (omega 12, $\mathrm{C}_{18}$ ). Interestingly, the unsaturated fatty acids that are classified as omega 6, 9, and 12 were more potent than omega 3 . Their molecular target and mode of action still remains unknown, even though there have been several reports that point to the cell membranes as a primary target [67]. Greenway, et al., [68] suggested that fatty acids with 18 carbons may have a surfactant-type action by increasing membrane 


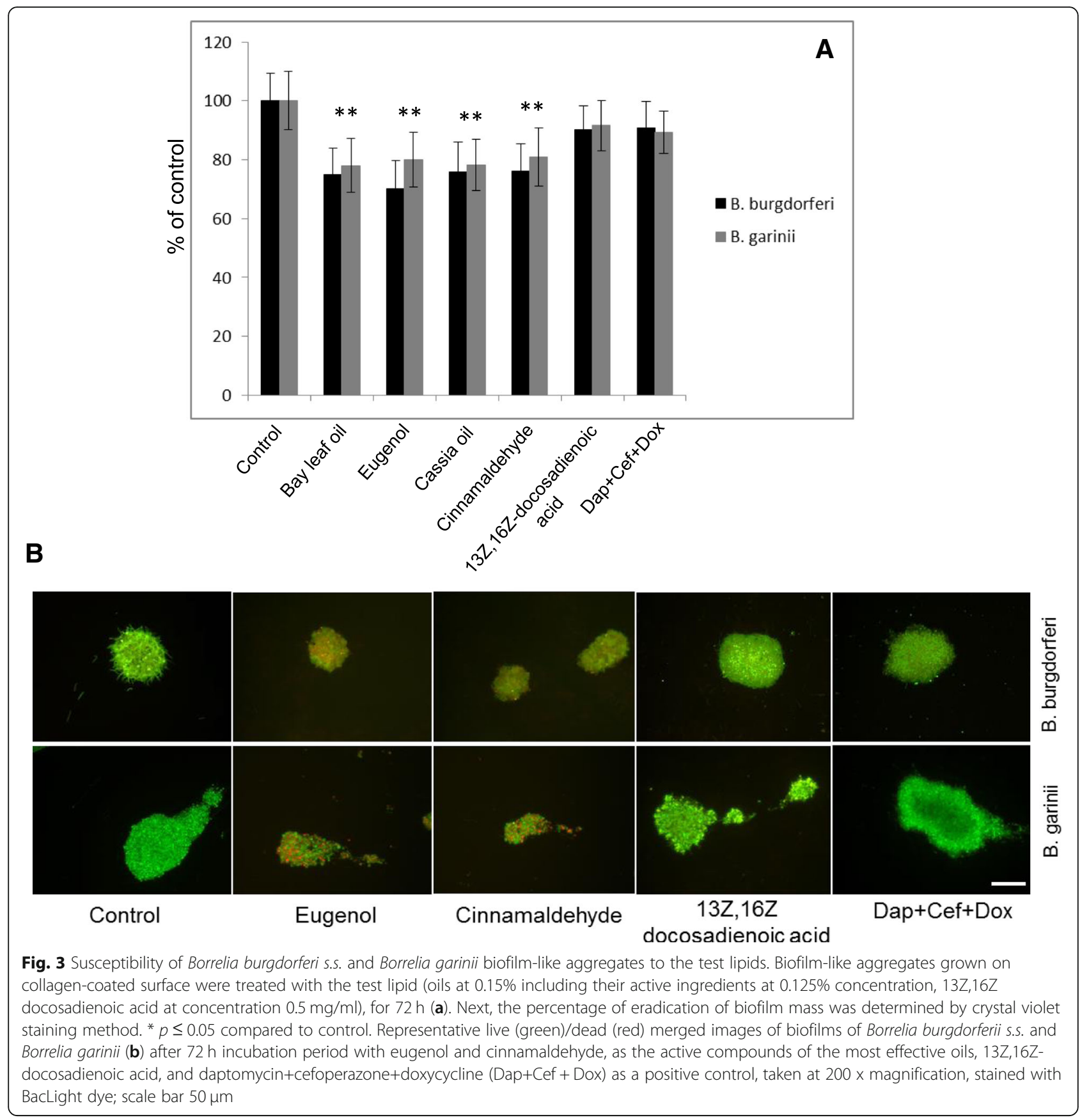

permeability. Others have suggested auto-oxidation products of unsaturated fatty acids that could be toxic to bacteria [69]. In addition, extensive pharmacokinetic, pharmacodynamics, and toxicological studies are warranted before extrapolating their applicability from bench to bedside.

\section{Conclusions}

Collectively, this study documents in vitro efficacy of a range of lipid compounds against active and latent forms of Borrelia burgdorferi sensu lato and indicate their being a promising non-synthetic alternative for combating these bacteria. These and earlier reported data by other groups support the hypothesis that organic oils in particular may be valuable and cost-efficient antimicrobials, and could be especially beneficial as topical or oral intervention in the case of other limited resources. Although further in vivo and human studies with attention paid to their safety are warranted, the organic oils could also become important antimicrobial agents improving the outcome of traditional treatments, and/or as an alternative option to conventional approaches. 


\section{Abbreviations}

CDC: Centers for Disease Control and Prevention; Cep: Cefoperazone; CV: Crystal violet; DAP: Daptomycin; DMSO: Dimethyl sulfoxide; Dox: Doxycycline; LD: Lyme disease; MBC: Minimal biocidal concentration; MIC: Minimal inhibitory concentration; PBS: Phosphate buffered saline; PI: Propidium iodide; PTLDS: Post-Treatment Lyme Disease Syndrome

\section{Acknowledgments}

The authors thank Cathy Flowers, BS and Waldemar Sumera, MS, for valuable input during preparation of the manuscript.

\section{Funding}

Funds were provided by the non- profit Dr. Rath Health Foundation, a separate entity from the Dr. Rath Research Institute BV. The founding sponsors had no role in the study design, performance, data collection and analysis, decision to publish, or preparation/writing of the manuscript.

\section{Availability of data and materials}

All data generated or analyzed during this study are included in this published article.

\section{Authors' contributions}

AG conceived, designed, and performed the experiments, analyzed data, wrote the paper and had primary responsibility for final content; AN and MR made substantial contributions to conception and design, and interpretation of data, wrote the paper and had primary responsibility for final content. All authors read and approved the final manuscript.

\section{Ethics approval and consent to participate} Not applicable.

\section{Consent for publication}

Not applicable.

\section{Competing interests}

AN is a member of the Dr. Rath Health Foundation and receives no revenues from it. No conflict of interest declared.

\section{Publisher's Note}

Springer Nature remains neutral with regard to jurisdictional claims in published maps and institutional affiliations.

Received: 1 May 2018 Accepted: 25 January 2019

\section{Published online: 04 February 2019}

\section{References}

1. Centers for Disease Control and Prevention. 2014 Lyme disease website. Available at: http://www.cdc.gov/lyme/. Accessed 13 Sept 2014.

2. Shapiro ED. Lyme disease. N Engl J Med. 2014;370:1724-31.

3. Brorson $\mathrm{O}$, Brorson SH. In vitro conversion of Borrelia burgdorferi to cystic forms in spinal fluid, and transformation to mobile spirochetes by incubation in BSK-H medium. Infection. 1998:26:144-50.

4. Murgia R, Cinco M. Induction of cystic forms by different stress conditions in Borrelia burgdorferi. APMIS. 2004;112:57-62.

5. Sapi E, Bastian SL, Mpoy CM, Scott S, Rattelle A, Pabbati N, Poruri A, Burugu D, Theophilus PA, Pham TV, Datar A, Dhaliwal NK, MacDonald A, Rossi MJ, Sinha SK, Luecke DF. Characterization of biofilm formation by Borrelia burgdorferi in vitro. PLoS One. 2012;7:e48277.

6. Sapi E, Kaur N, Anyanwu S, Luecke DF, Datar A, Patel S, Rossi M, StrickeR RB. Evaluation of in-vitro antibiotic susceptibility of different morphological forms of Borrelia burgdorferi. Infect Drug Resist. 2011:4:97-113.

7. Sapi E, Balasubramanian K, Poruri A, Maghsoudlou JS, Socarras KM, Timmaraju AV, Filush KR, Gupta K, Shaikh S, Theophilus PA, Luecke DF, MacDonald A, Zelger B. Evidence of in vivo existence of Borrelia biofilm in Borrelial Lymphocytomas. Eur J Microbiol Immunol (Bp). 2016;6:9-24

8. Straubinger RK, Summers BA, Chang YF, Appel MJ. Persistence of Borrelia burgdorferi in experimentally infected dogs after antibiotic treatment. J Clin Microbiol. 1997:35:111-6.

9. Embers ME, Barthold SW, Borda JT, Bowers L, Doyle L, Hodzic E, Jacobs MB, Hasenkampf NR, Martin DS, Narasimhan S, Phillippi-Falkenstein KM, Purcell JE, Ratterree MS, Philipp MT. Persistence of Borrelia burgdorferi in rhesus macaques following antibiotic treatment of disseminated infection. PLoS One. 2012:7:e29914.

10. Marques AS, Telford R, Turk SP, Chung E, Williams C, Dardick K, Krause PJ, Brandeburg C, Crowder CD, Carolan HE, Eshoo MW, Shaw PA, Hu LT. Xenodiagnosis to detect Borrelia burgdorferi infection: a first-in-human study. Clin Infect Dis. 2014:58:937-45.

11. Lantos PM, Auwaerter PG, Wormser GP. A systematic review of Borrelia burgdorferi morphologic variants does not support a role in chronic Lyme disease. Clin Infect Dis. 2014;58:663-71.

12. Cameron DJ, Johnson L, Maloney EL. Evidence assessments and guideline recommendations in Lyme disease: the clinical management of known tick bites, erythema migrans rashes and persistent disease. Expert Rev Anti-Infect Ther. 2014:12:1103-35.

13. Klempner MS, Baker PJ, Shapiro ED, Marques A, Dattwyler RJ, Halperin JJ, Wormser GP. Treatment trials for post-Lyme disease symptoms revisited. Am J Med. 2013;126:665-9.

14. Delong AK, Blossom B, Maloney EL, Phillips SE. Antibiotic retreatment of Lyme disease in patients with persistent symptoms: a biostatistical review of randomized, placebo-controlled, clinical trials. Contemp Clin Trials. 2012;33: 1132-42.

15. Fallon BA, Keilp JG, Corbera KM, Petkova E, Britton CB, Dwyer E, Slavov I, Cheng J, Dobkin J, Nelson DR, Sackeim HA. A randomized, placebocontrolled trial of repeated IV antibiotic therapy for Lyme encephalopathy. Neurology. 2008;70:992-1003

16. Loewen PS, Marra CA, Marra F. Systematic review of the treatment of early Lyme disease. Drugs. 1999;57:157-73.

17. Barthold SW, Hodzic E, Imai DM, Feng S, Yang X, Luft BJ. Ineffectiveness of tigecycline against persistent Borrelia burgdorferi. Antimicrob Agents Chemother. 2010;54:643-51.

18. Feng J, Zhang S, Shi W, Zhang Y. Ceftriaxone pulse dosing fails to eradicate biofilm-like microcolony B. Burgdorferi Persisters which are sterilized by Daptomycin/ doxycycline/cefuroxime without pulse dosing. Front Microbiol. 2016;7:1744-52.

19. Sharma B, Brown AV, Matluck NE, Hu LT, Lewis K. Borrelia burgdorferi, the causative agent of Lyme disease, forms drug-tolerant persister cells. Antimicrob Agents Chemother. 2015:59:4616-24.

20. Feng J, Auwaerter PG, Zhang Y. Drug combinations against Borrelia burgdorferi persisters in vitro: eradication achieved by using daptomycin, cefoperazone and doxycycline. PLoS One. 2015;10:e0117207.

21. Aucott JN, Rebman AW, Crowder LA, Kortte KB. Post-treatment Lyme disease syndrome symptomatology and the impact on life functioning: is there something here? Qual Life Res. 2013;22:75-84.

22. Brorson $\mathrm{O}$, Brorson $\mathrm{SH}$. Grapefruit seed extract is a powerful in vitro agent against motile and cystic forms of Borrelia burgdorferi sensu lato. Infection. 2007:35:206-8.

23. Liebold T, Straubinger RK, Rauwald HW. Growth inhibiting activity of lipophilic extracts from Dipsacus sylvestris Huds. Roots against Borrelia burgdorferi s. s. In vitro. Pharmazie. 2011;66:628-30.

24. Goc A, Niedzwiecki A, Rath M. In vitro evaluation of antibacterial activity of phytochemicals and micronutrients against Borrelia burgdorferi and Borrelia garinii. J Appl Microbiol. 2015;119:1561-72.

25. Goc A, Rath M. The anti-borreliae efficacy of phytochemicals and micronutrients: an update. Ther Adv Infect Dis. 2016:3:75-82.

26. Theophilus PA, Victoria MJ, Socarras KM, Filush KR, Gupta K, Luecke DF, Sapi E. Effectiveness of stevia Rebaudiana whole leaf extract against the various morphological forms of Borrelia Burgdorferi in vitro. Eur J Microbiol Immunol. (Bp). 2015;5:268-80.

27. Feng J, Zhang S, Shi W, Zubcevik N, Miklossy J, Zhang T. Selective Essential Oils from Spice or Culinary Herbs Have High Activity against Stationary Phase and Biofilm Borrelia burgdorferi. Front Med. (Lausanne). 2017:4:169.

28. Cowan MM. Plant products as antimicrobial agents. Clin Microbiol Rev. 1999:12:564-82

29. Morrison KC, Hergenrother PJ. Natural products as starting points for the synthesis of complex and diverse compounds. Nat Prod Rep. 2014;31:6-14.

30. Nazzaro F, Fratianni F, De Martino L, Coppola R, De Feo V. Effect of essential oils on pathogenic bacteria. Pharmaceuticals (Basel). 2013;6:1451-74.

31. Chouhan S, Sharma K, Guleria S. Antimicrobial activity of some essential oilspresent status and future perspectives. Medicines (Basel). 2017;4:E58.

32. Friedman $M$, Buick R, Elliott $C$. Antibacterial activities of naturally occurring compounds against antibiotic-resistant Bacillus cereus vegetative cells and spores, Escherichia coli, and Staphylococcus aureus. J Food Prot. 2004;67:1774-8. 
33. Maitland J, Fleming SA. Organic chemistry. United Kingdom: W. W. Norton \& Co Inc (Np); 1998.

34. Feng J, Wang T, Zhang S, Shi W, Zhang Y. An optimized SYBR green I/PI assay for rapid viability assessment and antibiotic susceptibility testing for Borrelia burgdorferi. PLoS One. 2014;9:e111809.

35. Singh O, Khanam Z, Misra N, Srivastava MK. Chamomile (Matricaria chamomilla L.): An overview. Appl Microbiol Biotechnol. 2010;85:1629-42.

36. Borugă O, Jianu C, Mișcă C, Goleț I, Gruia AT, Horhat FG. Thymus vulgaris essential oil: chemical composition and antimicrobial activity. J Med Life. 2014;7:56-60.

37. Tisserand R, Young R. Essential Oil Safety. United Kingdom: Churchill Livingstone Elsevier; 2013.

38. McHale D, Laurie WA, Woof MA. Composition of west Indian bay oils. Food Chem. 1977;2:19-25.

39. Ooi LS, Li Y, Kam SL, Wang H, Wong EY, Ooi VE. Antimicrobial activities of cinnamon oil and cinnamaldehyde from the Chinese medicinal herb Cinnamomum cassia Blume. Am J Chin Med. 2006:34:511-22.

40. Kabara JJ, Vrable R. Antimicrobial lipids: natural and synthetic fatty acids and monoglycerides. Lipids. 1977;12:753-9.

41. Kabara JJ, Swieczkowski DM, Conley AJ, Truant JP. Fatty acids and derivatives as antimicrobial agents. Antimicrob Agents Chemother. 1972;2:23-8.

42. Karbach J, Ebenezer S, Warnke PH, Behrens E, Al-Nawas B. Antimicrobial effect of Australian antibacterial essential oils as alternative to common antiseptic solutions against clinically relevant oral pathogens. Clin Lab. 2015; 61:616-8.

43. Martin KW, Ernst E. Herbal medicines for treatment of bacterial infections: a review of controlled clinical trials. J Antimicrob Chemother. 2003;51:241-6.

44. Melo AD, Amaral AF, Schaefer G, Luciano FB, de Andrade C, Costa LB, Rostagno MH. Antimicrobial effect against different bacterial strains and bacterial adaptation to essential oils used as feed additives. Can J Microbiol. 2015;61:263-71.

45. Leyva Salas M, Mounier J, Valence F, Coton M, Thierry A, Coton E. Antifungal microbial agents for food biopreservation-a review. Microorganisms. 2017;5:E37.

46. Pisoschi AM, Pop A, Georgescu C, Turcus V, Olah NK. Mathe EAn overview of natural antimicrobials role in food. Eur J Med Chem. 2018;143:922-35.

47. Draughon FA. Use of botanicals as biopreservatives in foods. Food Technol. 2004;58:20-8.

48. Chaieb K, Hajlaoui H, Zmantar T, Kahla-Nakbi AB, Rouabhia M, Mahdouani K, Bakhrouf A. The chemical composition and biological activity of clove essential oil, Eugenia caryophyllata (Syzigium aromaticum L. Myrtaceae): a short review. Phytother Res. 2007;21:501-6.

49. Yousef RT, Tawil GG. Antimicrobial activity of volatile oils. Pharmazie. 1980; 35:698-701.

50. Burt S. Essential oils: their antibacterial properties and potential applications in foods-a review. Int J Food Microbiol. 2004;94:223-53.

51. Smith-Palmer A, Stewart J, Fyfe L. Antimicrobial properties of plant essential oils and essences against five important food-borne pathogens. Lett Appl Microbiol. 1998;26:118-22.

52. Mayaud L, Carricajo A, Zhiri A, Aubert G. Comparison of bacteriostatic and bactericidal activity of 13 essential oils against strains with varying sensitivity to antibiotics. Lett Appl Microbiol. 2008:47:167-73.

53. Devi KP, Sakthivel R, Nisha SA, Suganthy N, Pandian SK. Eugenol alters the integrity of cell membrane and acts against the nosocomial pathogen Proteus mirabilis. Arch Pharm Res. 2013;36:282-92.

54. Trinh NT, Dumas E, Thanh ML, Degraeve P, Ben Amara C, Gharsallaoui A, Oulahal N. Effect of a Vietnamese Cinnamomum cassia essential oil and its major component trans-cinnamaldehyde on the cell viability, membrane integrity, membrane fluidity, and proton motive force of Listeria innocua. Can J Microbiol. 2015;61:263-71.

55. Cortés-Rojas DF, de Souza CR, Oliveira WP. Clove (Syzygium aromaticum): a precious spice. Asian Pac J Trop Biomed. 2014;4:90-6.

56. Nabavi SF, Di Lorenzo A, Izadi M, Sobarzo-Sánchez E, Daglia M, Nabavi SM. Antibacterial effects of cinnamon: from farm to food, cosmetic and pharmaceutical industries. Nutrients. 2015;7:7729-48.

57. Jayaprakasha GK, Rao LJ. Chemistry, biogenesis, and biological activities of Cinnamomum zeylanicum. Crit Rev Food Sci Nutr. 2011:51:547-62.

58. Chen BJ, Fu CS, Li GH, Wang XN, Lou HX, Ren DM, Shen T. Cinnamaldehyde analogues as potential therapeutic agents. Mini Rev Med Chem. 2017;17:33-43.

59. Desbois AP. Potential applications of antimicrobial fatty acids in medicine, agriculture and other industries. Recent Pat Antiinfect Drug Discov. 2012;7:111-22
60. Thormar $\mathrm{H}$, Hilmarsson $\mathrm{H}$. The role of microbicidal lipids in host defense against pathogens and their potential as therapeutic agents. Chem Phys Lipids. 2007;150:1-11.

61. Freese E, Shew CW, Galliers E. Function of lipophilic acids as antimicrobial food additives. Nature. 1979;241:321-5.

62. Sun CQ, O'Connor CJ, Roberton AM. Antibacterial actionsof fatty acids and monoglycerides against helicobacter pylori. FEMS Immunol Med Microbiol. 2003;36:9-17.

63. Desbois AP, Mearns-Spragg A, Smith VJ. A fatty acid from the diatom Phaeodactylumtricornutum is antibacterial against diverse bacteria including multi-resistant Staphylococcusaureus (MRSA). Mar Biotechnol. 2009;11:45-52.

64. Feldlaufer MF, Knox DA, Lusby WR, Shimanuki H. Antimicrobial activity of fatty acidsagainst Bacillus larvae, the causative agent of American foulbrood disease. Apidologie. 1993;24:95-9.

65. Seidel V . Taylor PW. In vitro activity of extracts and constituents of Pelagonium against rapidly growing mycobacteria. Int J Antimicrob Agents. 2004;23:613-9

66. Bergsson G, Arnfinnsson J, Steingrímsson Ó, Thormar H. Killing of grampositive cocci by fatty acids and monoglycerides. APMIS. 2001;109:670-8.

67. Heath RJ, White SW, Rock CO. Lipid biosynthesis as a target for antibacterial agents. Prog Lipid Res. 2001;40:467-97.

68. Greenway DLA, Dyke KGH. Mechanism of the inhibitory action of linoleic acid on the growth of Staphylococcus aureus. J Gen Microbiol. 1979;115:233-45.

69. Schauenstein E. Autoxidation of polyunsaturated esters in water: chemical structure and biological activity of the products. J Lipid Res. 1967;8:417-28.

\section{Ready to submit your research? Choose BMC and benefit from:}

- fast, convenient online submission

- thorough peer review by experienced researchers in your field

- rapid publication on acceptance

- support for research data, including large and complex data types

- gold Open Access which fosters wider collaboration and increased citations

- maximum visibility for your research: over $100 \mathrm{M}$ website views per year

At $\mathrm{BMC}$, research is always in progress.

Learn more biomedcentral.com/submissions 